\title{
KHASIAT MADU PADA PENYEMBUHAN LUKA KULIT
}

\author{
Sonny J. R. Kalangi \\ Bagian Anatomi-Histologi Fakultas Kedokteran Universitas Sam Ratulangi Manado \\ Email: sonnyjrkalangi@yahoo.com
}

\begin{abstract}
The topical application of honey on a wound is effective in controlling the wound healing process and results in clean granulation tissues in the wound base. Honey acts as a hyperosmolar medium and prevents microbial growth. Besides that, honey has a high viscosity that forms a physical barrier and cretaes a wet environmet which is very effective in accelerating wound healing. Nutrients in honey increase the supply of local substances that might be useful in reepithelization. In addition, honey contains a catalase enzyme that can influence wound healing.
\end{abstract}

Keywords: honey, wound healing

\begin{abstract}
Abstrak: Pemberian madu topikal efektif dalam mengontrol dan menghasilkan dasar luka bergranulasi bersih. Madu bekerja terutama sebagai medium hiperosmolar dan mencegah pertumbuhan bakteri. Madu juga memiliki viskositas tinggi yang membentuk sawar fisik dan menciptakan lingkungan basah; sifat tersebut yang membantu dan mempercepat penyembuhan luka. Kandungan bahan makanan dari madu menambah pasokan bahan lokal yang mungkin membantu mempercepat reepitelisasi. Disamping itu, madu mengandung enzim katalase yang juga mempengaruhi proses penyembuhan luka.
\end{abstract}

Kata kunci: madu, penyembuhan luka

Luka adalah suatu kerusakan fungsi dan struktur anatomi normal, sedangkan penyembuhan luka merupakan proses dinamik kompleks yang menghasilkan perbaikan fungsi dan kontinuitas anatomi. ${ }^{1}$ Proses penyembuhan luka merupakan masalah yang dihadapi sebagian besar klinikus, sementara itu kemampuan untuk mempercepat proses penyembuhan luka masih terbatas. Dalam penanganan terhadap luka dilakukan beberapa langkah dasar agar luka bersih, tidak terinfeksi, dan mencegah terjadinya perlukaan ulang. ${ }^{2}$

Pengobatan luka dengan menggunakan madu tercantum dalam papyrus Edwin Smith (1650 SM) ${ }^{3}$ yang merupakan salinan dari naskah asli sekitar tahun 3000-2500 SM. ${ }^{4}$ Pada Perang Dunia I, tentara-tentara telah menggunakan madu untuk tujuan pengobatan luka dan mulai saat itu nampak adanya dukungan ilmu pengetahuan terhadap kepercayaan ini. ${ }^{5}$

Madu merupakan campuran gula yang dibuat oleh lebah dari larutan gula alami yang disebut nectar yang dihasilkan dari bunga-bunga dan merupakan sumber energi yang baik. Madu hasil dari lebah yang ditampung dengan metode pengambilan moderen berupa cairan jernih dan bebas dari benda asing. ${ }^{6,7}$ Madu murni mengandung sekitar $40 \%$ glukosa, $40 \%$ fruktosa, dan $20 \%$ air. Selain itu, madu mengandung asam amino dan vitamin-vitamin termasuk bioten, asam nikotinat, asam folik, asam pantotenat, piridoksin, dan tiamin; juga ensim-ensim seperti diastase invertase, glukosa oksidase, dan katalase, serta mineralmineral berupa kalium, besi, magnesium, fosfor, tembaga, dan kalsium. ${ }^{5}$ Madu juga mengandung hidrogen peroksida yang dihasilkan oleh glukosa oksidase, inhibin, dan mempunyai kadar $\mathrm{pH}$ rendah $(3,6-3,7) .{ }^{5,8,9}$ 


\section{Khasiat madu pada penyembuhan luka kulit}

Madu mempunyai sifat-sifat kimia, fisik, dan biologik. Sifat-sifat tersebut meliputi: (1) debridement luka, (2) absorpsi cairan edema sekitar luka, (3) inaktivasi bakteri, (4) menghilangkan bau busuk luka, (5) mempercepat pembentukan jaringan granulasi dan epitelisasi, dan (6) menambah nutrisi. $^{10}$

Madu memiliki tekanan osmotik tinggi dan berfungsi terutama sebagai suatu medium hiperosmolar yang menyebabkan terjadinya aktivitas pembersihan luka dan mencegah pertumbuhan bakteri. ${ }^{9,11}$ Aktivitas pembersihan luka selain terjadi akibat sifat fisik madu juga dapat disebabkan oleh mekanisme kerja kimia atau ensimatik ${ }^{10}$ berupa pembersihan jaringan mati dan devitalisasi jaringan oleh ensim katalase. ${ }^{12}$ Ensim katalase yang terdapat pada madu ini juga bersifat antioksidan. ${ }^{11}$

Sifat higroskopik yang dimiliki madu memungkinkan terjadinya dehidrasi bakteri yang mengakibatkan bakteri dalam keadaan inaktif. Tanpa air, bakteri tidak dapat bereplikasi atau bertahan hidup. ${ }^{13}$ Sifat ini juga memungkinkan terjadinya dehidrasi luka edematosa dan lembab yang memperkecil luas permukaan luka. Dehidrasi ca-iran jaringan yang tidak dibutuhkan di sekitar luka akan menurunkan turgor jaringan dan meningkatkan oksigenasi jaringan yang membantu penyembuhan luka. ${ }^{10}$

Konsistensi madu yang memiliki viskositas tinggi membentuk sawar fisik yang mencegah luka dari penetrasi dan kolonisasi bakteri ${ }^{10}$ serta menciptakan suatu lingkungan basah yang sangat sesuai untuk epitelisasi dan dibutuhkan untuk penyembuhan luka yang optimal. ${ }^{11,14}$ Penyembuhan luka oleh pemberian madu topikal juga terjadi melalui inisiasi proses perbaikan luka dengan merangsang pembentukan jaringan granulasi melalui mekanisme 'cedera lokal' yang diakibatkan oleh efek iritasi granula madu. ${ }^{15}$

Kadar $\mathrm{pH}$ rendah dari madu membuat suatu kondisi lingkungan yang tidak menyokong untuk pertumbuhan bakteri, ${ }^{9}$ juga
pH asamnya meningkatkan vasodilatasi pembuluh darah yang mengalirkan darah dan kelenjar limfe menuju tempat luka. ${ }^{15}$

Kandungan nutrien madu meningkatkan suplai substrat lokal dan sebagai sumber energi yang baik dalam membantu mempercepat proses penyembuhan luka., ${ }^{6,11}$

Aktivitas antibakterial madu sebagian besar disebabkan oleh adanya hidrogen peroksida yang dihasilkan secara ensimatik pada madu. ${ }^{14}$ Kandungan hidrogen peroksida pada madu ini membantu dalam pembersihan luka melalui reaksi Fenton yang dengan mudah dapat menghasilkan radikal bebas hidroksil dengan efek bakterisidal. $^{7}$

Kandungan bahan antibakterial madu lainnya adalah inhibin, bahan termolabil ini diklaim oleh beberapa peneliti sebagai bahan antibakterial yang bertanggung jawab menghambat pertumbuhan organisme baik gram-positif maupun gram-negatif. ${ }^{5}$ Faktor inhibin ini nampaknya menjadi efektif karena hidrogen peroksida. ${ }^{11}$

Disamping berbagai kandungan bahan antibakterial dari madu yang telah diketahui, terdapat juga beberapa jenis madu dengan bahan kandungan tambahan yang bersifat antibakterial berupa komponen yang berasal dari tanaman yang dikunjungi lebah. ${ }^{14}$

\section{Implikasi klinik}

Baik pengamatan klinik maupun sejumlah kecil studi kontrol memberikan konfirmasi terhadap sifat-sifat madu yang digunakan secara topikal dalam mempercepat penyembuhan luka. Penyembuhan cepat telah dilaporkan pada pemberian madu secara topikal terhadap luka-luka seperti: ulkus, gangren, luka bakar, dan luka pasca bedah. ${ }^{12-19}$

\section{SIMPULAN}

Pemberian madu topikal efektif menghasilkan dasar luka bergranulasi bersih. Madu bekerja sebagai medium hiperosmolar dan mencegah pertumbuhan bakteri, juga memiliki viskositas tinggi yang mem- 
bentuk sawar fisik dan menciptakan lingkungan basah yang mempercepat penyembuhan luka. Kandungan nutrien madu menambah pasokan bahan lokal dan mungkin membantu mempercepat reepitelisasi. Disamping itu, madu mengandung enzim katalase yang juga mempengaruhi proses penyembuhan luka.

\section{SARAN}

Karena kemungkinan variasi musiman dan perbedaan dalam pengolahan dan kemasan dari madu, juga adanya peringatan terhadap penggunaan madu yang tidak steril dalam pengobatan medis maka penting dilakukan proses pengambilan dan pemeriksaan terhadap bahan madu yang akan dipakai dalam pengobatan medis.

\section{DAFTAR PUSTAKA}

\section{Lazarus GS, Cooper DM, Knighton DR,} Margolis DJ, Pecoraro RE, Rodeheaver G, et al. Definition and guidelines for assessment of wounds and evaluation of healing. Arch Dermatol. 1994;130:489-93.

2. Gupta SS, Singh O, Bhagel PS, Moses S, Shukla S, Mathur RK. Honey dressing versus silver sulfadiazene dressing for wound healing in burn patients: A retrospective study. J Cutan Aesthet Surg. 2011 4(3):183-7.

3. Caldwell MD. Topical wound therapy - A historical perspective. J Trauma. 1990;30(12 Suppl.):S116-S122.

4. Dealey C. The Care of Wounds. Oxford: Blackwell Science, 1994.

5. Dai T, Huang YY, Sharma SK, Hashmi JT, Kurup DB, Hamblin MR. Topical antimicrobials for burn wound infections. Recent Pat Antiinfect Drug Discov. 2010;5(2):124-51.

6. Subrahmanyam M. Topical application of honey for burn wound treatment - an overview. Ann Burns Fire Disast. 2007;20(3):137-9.

7. Majtan J. Methylglyoxal - A potential risk factor of Manuka honey in healing of diabetic ulcers. Evidence-Based Complementary and Alternative Medicine, Volume 2011, 1-5. Article ID 295494. doi:10.1093/ecam/neq013.
8. Allen KL, Molan PC, Reid GM. A survey of the antibacterial activity of some New Zealand honeys. J Pharm Pharmacol. 1991;43:817-22.

9. Hall M. Minor burns and hand burns: comparing treatment methods. Prof Nurse. 1997;12(7): 489-91.

10. Mohapatra DP, Thakur V, Brar SK. Antibacterial efficacy of raw and processed honey. Biotechnol Res Int. Volume 2011, 1-6. Article ID 917505. doi:10.4061/2011/917505.

11. Sherlock O, Dolan A, Athman R, Power A, Gethin G, Cowman S, Humphreys H. Comparison of the antimicrobial activity of Ulmo honey from Chile and Manuka honey against methicillinresistant Staphylococcus aureus, Escherichia coli and Pseudomonas aeruginosa. BMC Complement Alternat Med. 2010;10(47):1-5.

12. Irish J, Blair S, Carter DA. The antibacterial activity of honey derived from Australian flora. PLoS ONE [serial on the internet] 2011. [2011 Nov 10];6(3):1-9. Available at: www. plosone.org

13. Condon RE. Curios interaction of bugs and bees (editorial). Surgery. 1993;113: 234-5.

14. Maghsoudi H, Salehi F, Khosrowshahi MK, Baghaei $M$, Nasirzadeh $M$, Shams R. Comparison between topical honey and mafenide acetate in treatment of burn wounds. Ann Burns Fire Disast. 2011;24(3):132-7.

15. Olaitan PB, Adeleke OE, Ola IO. Honey: a reservoir for microorganisms and an inhibitory agent for microbes. Afr Health Sci. 2007;7(3):159-65.

16. Cooper R. Honey in wound care: antibacterial properties. GMS Krankenhaushygiene Interdisziplinär. 2007;2(2):1-3.

17. Tan MK, Adli DSH, Tumiran MA, Abdulla MA, Yusoff KM. The efficacy of Gelam honey dressing towards excisional wound healing. Evidence-Based Complement Alternat Med. Volume 2012, 1-6. Article ID 805932. doi:10.1155/2012/805932

18. Sukur SM, Halim AS, Singh KKB. Evaluations of bacterial contaminated full thickness burn wound healing in Sprague Dawley rats treated with 
166 Jurnal Biomedik, Volume 4, Nomor 3, November 2012, hlm. 163-166

Tualang honey. Indian J Plast Surg. 2011; 44(1):112-7.

19. Al Waili NS, Saloom KY. Effects of topical honey on post-operative wound infections due to gram positive and gram negative bacteria following caesarean sections and hysterectomies. Eur J Med Res. 1999;4(3):126-30. 